Article

\title{
Blurred Boundaries: Ethnofiction and Its Impact on Postwar Japanese Cinema
}

\author{
Jennifer Coates \\ Sainsbury Institute for the Study of Japanese Arts and Cultures, University of East Anglia, \\ Norwich NR14DH, UK; j.coates@sainsbury-institute.org
}

Received: 24 December 2018; Accepted: 31 January 2019; Published: 2 February 2019

check for updates

\begin{abstract}
This article explores the use of ethnofiction, a technique emerging from the field of visual anthropology, which blends documentary and fiction filmmaking for ethnographic purposes. From Imamura Shōhei's A Man Vanishes (Ningen jōhatsu, 1967) to Hou Hsiao Hsien's Cafe Lumieré (Kōhi jikō, 2003), Japanese cinema, including Japan-set and Japan-associated cinema, has employed ethnofiction filmmaking techniques to alternately exploit and circumvent the structural barriers to filmmaking found in everyday life. Yet the dominant understanding in Japanese visual ethnography positions ethnofiction as an imported genre, reaching Japan through Jean Rouch and French cinema-verité. Blending visual analysis of Imamura and Hou's ethnofiction films with an auto-ethnographic account of my own experience of four years of visual anthropology in Kansai, I interrogate the organizational barriers constructed around geographical perception and genre definition to argue for ethnofiction as a filmmaking technique that simultaneously emerged in French cinema-verite and Japanese feature filmmaking of the 1960s. Blurring the boundaries between Japanese, French, and East Asian co-production films, and between documentary and fiction genres, allows us to understand ethnofiction as a truly global innovation, with certain regional specificities.
\end{abstract}

Keywords: ethnofiction; Japan; documentary; non-fiction; dramatization

\section{Introduction}

Scholarship on global cinemas is scarred by a number of organizational barriers. One of the most detrimental to a holistic understanding of the field may be the division of film texts along national lines, and by genre. In practice, such divisions are often meaningless. A significant number of filmmakers innovate across national boundaries in relation to setting, funding, casting, and exhibition, while genre-defying film texts have tested scholarly definition since the beginning of Film Studies. Certain key trends in Japanese feature filmmaking clearly illustrate the value of taking a more inclusive approach to understanding genre development, thematic trends, and technical innovation. This article explores Japanese cinema's use of ethnofiction, a technique associated with visual anthropology that blends documentary and fiction filmmaking for ethnographic purposes. From Imamura Shōhei's A Man Vanishes (Ningen jōhatsu, 1967) to Hou Hsiao Hsien's Cafe Lumieré (Kōhi jikō, 2003), postwar Japanese feature films, including Japan-set and Japan-associated films, have employed ethnofiction filmmaking techniques to explore the human condition, alternately exploiting and circumventing the structural barriers to filmmaking that are presented by the physical constraints of bringing a camera into everyday lives and spaces. Feature films such as Imamura and Hou's discussed below draw from spontaneously occurring events in the lives of everyday people, and from the environments in which these people live, to create semi-documentary or partly fictionalized stories. The close relation that these stories bear to a lived reality or perceived truth then allows the filmmaker to make claims about their depiction of an imagined human condition. 
As the first part of this article demonstrates, fictionalized elements including staging, re-enactment, the use of props, and scripted scenes and dialogue, have been a part of the broader genre of documentary film in Japan since the beginnings of film itself. Yet in the field of anthropology, the dominant understanding in Japanese visual ethnography positions ethnofiction as an imported genre, arriving in Japan in the late 1950s through the work of Jean Rouch and French cinema verité. Blending analysis of Imamura and Hou's ethnofiction films with an auto-ethnographic account of my own experience of four years of visual anthropology work in Kansai, I interrogate the organizational barriers constructed around geographical and genre definitions to argue for ethnofiction as a filmmaking technique that simultaneously developed in French cinema verité and Japanese feature filmmaking of the 1950s, 1960s, and 1970s, continuing to influence contemporary filmmaking in East Asia today. While it is not possible within the limits of this essay to deal with the development of ethnofiction techniques in commercial filmmaking through the 1980s and 1990s, I hope these two examples from either end of the postwar ethnofiction trend demonstrate how the technique became more mainstream, both across genres and across East Asia more broadly. Blurring the boundaries between Japanese, French, and East Asian filmmaking, and between documentary and fiction genres, allows us to understand ethnofiction as a truly global innovation, with certain regional specificities.

There are numerous definitions of ethnofiction (also written ethno-fiction), but for the purposes of this article I will use the definition adopted by the ethnofiction study group I joined at The National Museum of Ethnography in Osaka, Japan. As the last section of this article describes, the study group was largely comprised of Japanese practice-based researchers in the field of anthropology, working in fieldsites other than Japan. During the making of my own documentary film on memories of postwar cinema in Japan (Coates 2018), I screened several of Imamura's films for the group, initiating an on-going discussion about the history of ethnofiction filmmaking in Japan outside the specific scholarly field of anthropology.

Group members worked from Johannes Sjöberg's outline of ethnofiction as a genre in which "the camera simply follows the subjects' improvisations of their own, and others', lived experiences" (Sjöberg 2008, p. 229). Sjöberg identifies ethnofiction as emerging in 1950s France in the work of director Jean Rouch, and the term as a coinage of the film critics of the era (Sjöberg 2008, p. 229). Paul Stoller describes Rouch's method as follows:

It is not a documentary that attempts to capture an observed reality. By the same token it is not a melodrama the filmmakers dreamed up to titillate our emotions ... These films are stories based on laboriously researched and carefully analysed ethnography. In this way Rouch uses creative licence to "capture" the texture of an event, the ethos of lived experience (Stoller 1992, p. 143).

While I am arguing here for the development of ethnofiction filmmaking as multi-local and simultaneous, as well as for more scholarly blurring of the boundaries between documentary and feature film, the "varying degrees of commitment to ethnographic research that was represented through fiction" in Rouch's work (Sjöberg 2008, p. 230) provides a working definition of the term ethnofiction for the discussion that follows. However, I do not wish to imply that any director, auteur, or even anthropologist may be credited with independently developing something like a 'true' ethnofiction. Given the formal and informal media flows of the 1950s and 1960s, including amateur film club screenings and study group screenings conducted in the Japanese film studio workplaces which are difficult to trace, it is not possible to argue with any certainty that the filmmakers discussed below were not influenced by one another's films and methods. Instead, I wish to demonstrate how ethnofiction is presented in filmmakers' own discourse as a commonsense technique for developing and communicating stories about everyday life. The final paragraphs contrast this approach to ethnofiction-like techniques with the more canonical account of ethnofiction in visual anthropology in Japan today. 


\section{Results}

\subsection{Early Ethnofictions and the Problem of Terminology}

The question of language is crucial to understanding the emergence and development of techniques such as ethnofiction in two broad aspects-definition and translation. When we speak across disciplinary boundaries and language barriers, we are often using different words to talk about the same phenomenon, or conversely, using shared terms to discuss very different concepts. Tracing the emergence and development of ethnofiction through Japanese cinema history makes clear the confusions, misunderstandings, and miscommunications that can occur when we try to discuss visual techniques in multiple languages, and from different academic fields or perspectives.

Focusing first on the question of definition, it is clear that this problem is not unique to ethnofiction filmmaking. In fact, the multiple origin stories of filmmaking and cinema exhibition in Japan revolve around the question of our definition of "cinema". Closely following the arrival of Thomas Edison's Kinetoscope in Kobe in November 1896, and the Vitascope in 1897, the Lumière brothers' Cinematograph was brought to Japan by businessman Inabata Katsutarō. While Edison's technology was exhibited in the style of an interactive museum object, with viewers approaching the Kinetoscope one by one to look through the lens, Inabata hosted the first open commercial film screening at the Nanchi Enbujo Theatre in Osaka from 15 February 1897 after a two-week trial screening in Kyoto from 20 January 1987. The commercial Kyoto screening later opened to the public in March 1897. Kobe, Kyoto, and Osaka city governments have all erected plaques claiming their respective sites as the birthplace of cinema in Japan. Was Kobe's technological exhibition, Kyoto's public theatre-style screening, or Osaka's commercial fee-paying event the first instance of cinema in Japan? It all depends on your definition of "cinema".

In addition to bringing the Lumières' apparatus to Japan, Inabata was also influential in bringing the first images of Japanese everyday life to global film audiences, though the version he was involved in creating was perhaps closer to ethnofiction than classical documentary. Francois-Constant Girel, a Lumière cameraman who travelled to Japan with Inabata, was encouraged by his host to film the elite life of the Inabata family, showing members at dinner and engaging in domestic and social activities (Toki and Mizoguchi 1993). These images showed a marked contrast to the orientalist exotica that the Lumière cameramen recorded in Japan, such as The Ainu of Ezo (Les Ainu a yeso, 1897), Japanese Fencing (Escrime au sabre japonaise, 1897), Japanese Actors (Auteurs japonais, 1898), and Geisha Riding in Rickshaws (Geishas en jinrikisha, 1898). Inabata appeared determined to ensure that the cameramen returned to Europe with recordings of Japanese life that challenged any idea of Japan as quaint, backwards, or uncivilized.

The influence of Inabata's engineered representations of everyday life in Japan is clear in these first cinematic recordings, blurring documentary and scripted re-presentation. These early films can be understood as ethnographic in their intention, attempting to show how everyday people were living in Japan to audiences on the other side of the world. At the same time, they already contained fictionalized elements of a propagandistic nature. Non-Japanese cameramen emphasized difference, exoticizing the representation of Japan in order to increase the attractiveness of their footage for viewers in Europe. Wealthy and worldly participants such as Inabata instead insisted on an equally fictionalized representation of Japanese people as models of civilization and Westernized deportment, demonstrating the use of Anglo-European customs, furnishings, fashions, and utensils in early twentieth century Japan.

This early engineering of the nation's public image was quick to catch on in Japanese filmmaking. News films visualized the exciting developments of the early twentieth century for domestic audiences, focusing on glorified stories such as Japan's success in the Russo-Japanese war of 1904. Hiroshi Komatsu identifies a degree of fictionalization at this early stage of news reporting, distinguishing constructed news films (kōseisareta nyūsu eiga) from fake news films (nisei nyūsu eiga) (Komatsu 1994). Re-enactments, stage sets, and props including miniature models were used in constructed news 
films based on real events, often mixed with reportage from scenes of battle. Fake news films showed re-enactments of events filmed outdoors, including imagined dramatic death scenes. While these "fake documentaries" (Komatsu 1994) can be attributed to the lack of available documentary footage of the war, the practice of fictionalizing and re-staging events continued even after the 1905 ratification of the Treaty of Portsmouth that ended the war.

It is important to note that these early war films, like those to follow in the 1930s and 1940s, no longer followed the ethnographic imperatives of the earliest film recordings. Propagandistic goals supported increasing fictionalization, as censors and filmmakers strove to represent the Japanese military effort favorably. Before the strict censorship of the 1930s however, the end of the Russo-Japanese war saw a decline in the production of war films, documentary or otherwise. As cinema theatre content moved on from war films to "slapstick, comedy, tragedy, fairy tale, and historical dramas" (Anonymous 1910, p. 21, trans. Gerow 1994), little distinction was made between observational recordings of spontaneous occurrences, and scripted, enacted, or created content. Overall, Komatsu argues, writers on film culture of the early 1900s appeared "not [to] possess a cinematic point of view presupposing the concept of fiction; accordingly, the idea of nonfiction does not exist for him [sic] either" (Komatsu 1994). As such, we can understand the prewar and interwar news and documentary films featuring fictionalized elements as a kind of early ethnofiction, with a strong connection to the more fully developed ethnofiction films of the postwar period.

The translation of key terms and genre nomenclature further disrupted the possibility of clearly defining fiction from documentary film. As Hikari Hori notes, the role of translator and scenario writer Atsugi Taka was crucial here. Atsugi translated Paul Rotha's 1935 Documentary Film, which was published in Japan in 1938 under the title Bunka eiga ron. Hori translates the title as "Treatise on Culture Film" in order to emphasize the difference between "documentary" and "culture film" as the genres are understood today (Hori 2018, p. 117). The Kyoto-based publisher Daiichi geibun sha recommended that the title should include the term bunka eiga, on the grounds that it was "one of the better-known terms for nonfiction films in Japan" (Hori 2018, p. 117). Yet Atsugi also used the word dokyumentari (a phonetic transcription of "documentary") throughout the translated text, and her translation spread the term dokyumentari widely across Japan (Hori 2018, p. 117).

Rotha himself was not against "creative dramatization of actuality" in documentary film (Hori 2018, p. 131), intentionally conflating the genres of documentary and dramatic films and promoting the use of fictionalized and re-staged episodes in documentary filmmaking (Higson 1995, p. 204). The use of amateur actors "was practiced as part of Rotha's reception" (Hori 2018, p. 142), though the method has previously been understood in Japan as promoted by Soviet directors such as Vsevolod Pudovkin and Sergei Eisenstein. Yet the degree to which fictionalization was considered acceptable was much debated. Critic Iwasaki Akira denounced Kamei Fumio's Fighting Soldiers (Tatakau heitai, 1939) as exemplifying the trend for abusing "dramatization" by using acting too freely (Hori 2018, p. 131). Iwasaki argued that the term "dramatization" had become almost a "slogan" in "the new school of culture film" (Hori 2018, p. 131). Yet he did not advocate abandoning the practice entirely. Instead, he argued that the purpose of dramatization should be to "introduce the voices of people and social issues" (Hori 2018, p. 132). Iwasaki's focus on the use of dramatization to foreground the voices of everyday people and their concerns suggest the ethnographic imperative. Yet the political mood of the moment saw this goal superseded by the use value of cinema as a tool of political persuasion. Iwasaki recommended that culture film become more "argumentative" (shuchōsei), moving on from simply recording a subject to persuading the audience of a political objective as a kind "argument film" (giron eiga) or "thought film" (shisō eiga) (Hori 2018, p. 132).

While recognizing the practice of dramatization and the use of actors as widespread in the documentary and culture films of the 1930s, Iwasaki located a second stage of fictionalization in the editing of drama and documentary genres alike. "Living actuality fast becomes artistic reality when it is selected, edited, and formed, and since this is when truth appears, documentary cinema is also no different from the fiction of theatrical film" (Iwasaki quoted in Sugiyama 1990, p. 179, trans. 
Nornes 2003, p. 101). The wartime Japanese government came to similar conclusions in 1939 on the passing of the Film Law, which privileged the screening of documentary film over fiction film, and at the same time drew a wide marker around the definition of documentary. In 1939, the Education Ministry recognized 985 documentary films, while registered documentary films totaled 4460 by 1940 (Naimushō keihōkyoku 1941, p. 103; quoted in Kasza 1993, p. 240). Markus Nornes argues that, "by the end of the 1930s it would be more appropriate to conceptualize fiction and nonfiction as two overlapping spheres with constant flux between them" (Nornes 2003, p. 95). We can see a similar attitude in the more fully developed ethnofiction films of the postwar.

While this history lays the ground for the development of ethnofiction filmmaking in the postwar era, it is important to note that fictionalization in the service of propaganda is of a different order to the research-based and participant-led fictionalizations of filmmakers such as Rouch and Imamura in the 1950s and 1960s. The 1930s "blurring of the boundary between fiction and documentary film" (Nornes 2003, p. 97) developed into a second era of wartime filmmaking that blended documentary recordings of actual events into fictional narrative structures. Narrative fiction films such as Dawn of Freedom (Ano hata o ute, Abe Yutaka and Geraldo de Leon, 1944) included recordings of real events taken at the time of their occurrence, as well as footage of people re-enacting recent events from their own experience, for example, American prisoners of war re-enacting their own defeat and surrender. Such techniques fell out of favor after the war, perhaps tainted for audiences by memories of wartime propaganda. Occupation era (1945-1952) censorship scrutinized films for references to the war and the Occupation itself, restricting the exhibition of spontaneously recorded footage of real-life events, as the representation of Occupation personnel, English language signage, black market dealing, and other everyday occurrences were banned.

While the early postwar film industry re-focused largely on narrative film, with the exception of Kamei Fumio's ill-fated Tragedy of Japan (Nippon no higeki, 1947), a return to documentary style filmmaking in the early 1950s included from its beginning an element of ethnofiction or scripted reality. Nornes argues that "the first questioning of postwar realism" began in 1957, when the nature documentary The White Mountains (Shiroi sanmyaku, 1957) was found to include species from other environments, and even a stuffed bear (Nornes 2002, p. 43). In the late 1950s and early 1960s, documentary filmmaking began to move back towards the cinema verité or ethnofiction style of the wartime and pre-war. While Hani Susumu's well-regarded Children of the Classroom (Kyōshitsu no kodomotachi, 1954) and Children Who Draw (E o kaku kodomotachi, 1955) observed the largely non-interventionist methods of direct cinema, by Bad Boys (Furyō shōnen, 1961) the director was employing the residents of a home for delinquent youths to play characters based on themselves, re-enacting experiences told to the filmmaker.

Ethnofiction, or the use of fictionalized or dramatized elements in the representation of a factual or historical event or situation, significantly predated the 1960s global boom in practice and discussion of the technique. Drawing from Japanese cinema's long blurring of the boundaries between fiction and non-fiction, the next section of this article investigates the work of experimental director Imamura Shōhei, a near contemporary of Jean Rouch. Examining Imamura's first uses of ethnofiction filmmaking techniques, I argue for the development of ethnofiction in Japan as near-simultaneous with its French counterpart, rather than a later import from France, as it is commonly understood in the field of Japanese anthropology. Like Kamei Fumio, who borrowed Erik Barnouw's notion of "parallel developments" to argue that "the genre of documentary film was simultaneously emerging globally" (Hori 2018, p. 130), I am suggesting that ethnofiction developed in parallel in Japan and Europe in the 1950s and 1960s, contextualized by the historical blurring of the boundaries between documentary and fiction film in the first half of the twentieth century in Japan.

\section{2. "Between Fiction and Documentary" in Japan: The Ethnofictions of Imamura Shōhei}

While Jean Rouch was establishing ethnofiction in France, a new generation of filmmakers were emerging in Japan. Shōchiku studio personnel were keen to connect these young innovators to 
developments in France, despite the filmmakers' resistance. At Nikkatsu studios, Imamura's first three films were released in quick succession throughout 1958, all classic studio era narrative fiction features. Throughout his career, Imamura became progressively more committed to exploring and representing human nature. The director famously referred to himself as an "anthropologist" asking, "What is a human being? I look for the answer by continuing to make films" (Laprévotte 1997, p. 101). From the 1960s on, Imamura began to weave some of the documentary filmmaking techniques associated with anthropology into his studio films.

For example, The Insect Woman (Nippon konchūki, 1963) follows the protagonist (Hidari Sachiko) from youth to middle age, depicting a woman who, like an insect, simply exists while life goes on around her. The scenario was influenced by the life story of a living woman, and re-written so that it could be filmed in a "fly on the wall" documentary style (Mihalopoulos 2008, p. 282). Though the protagonist is played by a professional actress, the film style reflects the mood of an ethnofiction film in which "the camera simply follows the subjects' improvisations of their own, and others', lived experiences" (Sjöberg 2008, p. 229). We can think of Hidari's performance under Imamura's direction as a kind of joint improvisation of "others' lived experiences". Stoller defines ethnofiction films as "stories based on laboriously researched and carefully analysed ethnography" (1992, p. 143). While Imamura's use of a living woman's memories doesn't quite constitute laborious research, the mood of The Insect Woman certainly echoes the "way Rouch uses creative licence to "capture" the texture of an event, the ethos of lived experience" (Stoller 1992, p. 143), with the "varying degrees of commitment to ethnographic research" found in Rouch's work (Sjöberg 2008, p. 230). When questioned about his research process by interviewer Nakata Toichi, Imamura reflected that, "It may be that some of my fiction films look a bit like documentaries because I base my characters on research into real people" (Imamura trans. Nakata 1997, p. 116). While Imamura was by no means the first or only proponent of ethnofiction filmmaking techniques in postwar Japan, his account of practicing "research into real people" as the basis of narrative development highlights the shift from ethnofiction-like practices in the prewar and wartime eras that focused on recreating historical events, to the postwar use of ethnofiction to explore the human condition in an anthropological manner.

In 1965, Imamura left Nikkatsu to establish Imamura Productions, and his first independent film, The Pornographers, made explicit his deepening interest in anthropology and its methods. The title is literally translated as "An Introduction to Anthropology by Pornographers" (Erogotoshitachi yori jinruigaku nyūmon, 1966). The plot was adapted from a novel by Nosaka Akiyuki. Yet on recalling this period, Imamura returns to his emphasis on the idea of generating film content directly from human experience.

For me, the idea for the film lies in its attitude to human beings. In my case, this attitude is one of obsession ... . In my work, people take centre stage. I am much more interested in mankind than I am in other filmmakers (Imamura 1997, p. 125).

Imamura addresses the gap between fiction and documentary in his films of this era in a chapter titled "Between Fiction and Documentary" (Fikushon to dokyumentari no awai de) (Imamura 2001). Recalling the early years of Imamura Productions, he remembers working simultaneously on plans for A Man Vanishes while writing the scenario for The Pornographers, and drafting The Profound Desire of the Gods (Kamigami no fukaki yokubō, 1968) (Imamura 2001, p. 234). While A Man Vanishes was completed a year before The Profound Desire of the Gods, working like this, Imamura recalled feeling that the two films "blur into one" (Imamura 2017, translated by Mihalopoulos 2017, p. 103). While The Profound Desire of the Gods is perhaps Imamura's most explicitly ethnographic film, A Man Vanishes was similarly developed through a process of researching a particular event, finding and enlisting participants to play versions of themselves, and following their movements with a film crew. Author of The Pornographers Nosaka Akiyuki was also invited to co-write A Man Vanishes, which wears its provocations openly.

Originally intending to investigate twenty-six cases of disappearances in postwar Japan, in the end, Imamura focused on the remnants of one specific family (Nakata 1997, p. 117). Protagonist Hayakawa Yoshie searches for her husband, who has disappeared, as Imamura's camera follows her 
less than surreptitiously. Imamura's "research" included lodging himself and his crew in the room next door to Hayakawa for one year, observing her "every bad quality imaginable" (Imamura quoted in Nakata 1997, p. 118). Actor Tsuyuguchi Shigeru played the role of interviewer, and Imamura instructed him to romance Hayakawa to draw out the grasping side of her nature. When Tsuyuguchi expressed dismay at Hayakawa's romantic interest in him, Imamura allowed himself to be captured on camera urging him on, "That's exactly what I want". "So much for cinema verité" critic Donald Richie wrote archly of this scene (Richie 2005, p. 189). In fact, Imamura's open depiction of how he manipulated the real people playing versions of themselves in his film recalls Jean Rouch's own presence in Chronicle of a Summer (Chronique d'un été, 1961), specifically the scene in which he persuades a reluctant Marcelline Rozenberg to speak about her time in Auchwitz-Birkenau, before encouraging the other participants to turn on her critically.

As in much of his previous work, Imamura remains attracted to the space between documentary and fiction, or truth and fiction, in content as well as form. As A Man Vanishes builds to a climax, this becomes the film's central theme. Sitting in a small private dining room of an inn or restaurant, Hayakawa Yoshie confronts her sister Sayo in the presence of Imamura and Tsuyuguchi. "What is truth?" asks Hayakawa, and on cue, the walls of the room fall away, the lights become brighter, and the camera moves out to reveal that the room sits in the centre of a film studio. Imamura answers, "This is fiction". Richie claims that only Imamura knew what was about to happen (Richie 2005, p. 190), but the viewer questions how the protagonists could have been brought to the room without realizing that the structure was not part of a regular restaurant building. Imamura would only say, "I collapsed the set in the end with the intention of revealing the betwixt of drama and documentary" (Imamura 2017, translated by Mihalopoulos 2017, p. 103). Here, we can see an element of fictionalization in the discourse surrounding the film, as well as the film itself, in that certain details are omitted or manipulated to preserve the auteur's persona. Imamura's accounts of both the practical elements of creating such scenes, and the use of documentary and ethnofiction-style techniques more broadly, should be understood in relation to his budding auteur persona, arguably better served by a focus on his innovations than by references to other filmmakers such as Rouch.

In his interview with Nakata, Imamura expressed regret at the deception of Hayakawa during filmmaking. While he stressed that she had "given her explicit consent" to being filmed, she was not aware of the hidden cameras used to film some of the footage (Nakata 1997, p. 118). Hayakawa had taken time off work for the project, and was paid a salary. Imamura asserted that "she approached the project as a job, and she soon took on the role of an actress in front of the camera" (Nakata 1997, p. 118). While he argued that, "She used the cameras as much as we used her as a subject", he acknowledged the "serious ethical questions involved" in the treatment of Hayakawa during filmmaking (Nakata 1997, p. 118). Yet he invoked the ethnographic aspect of the project as an excuse for the risk to which Hayakawa was exposed, arguing that while she did not know what the outcome of the project would be, "we behind the camera didn't know where reality was going to lead us either" (Imamura quoted in Nakata 1997, p. 118).

In the end, Imamura recalled the experience of making A Man Vanishes as leading to his realization that "fiction—no matter how close to reality—could never be as truthful as unmediated documentary" (Imamura quoted in Nakata 1997, p. 118). In the early 1970s, he began a series of documentaries for Tokyo Channel 12 television channel dealing with the lives of former Japanese soldiers of the Japanese Imperial Army living in Southeast Asia: In Search of the Unreturned Soldiers in Malaysia (Mikikanhei o otte-Marei-hen, 1971), In Search of the Unreturned Soldiers in Thailand (Mikikanhei o otte-Tai-hen, 1971), and Outlaw Matsu Returns (Muhomatsu kokyō ni kaeru, 1973). The last playfully blends the titles of 1950s fiction film hits The Rickshaw Man (Muhomatsu no issho, Inagaki Hiroshi, 1958) and Carmen Comes Home (Karumen kyokō ni kaeru, Kinoshita Keisuke, 1951), suggesting that even these straight documentaries have some connection to the fictionalized worlds of narrative cinema.

Imamura stepped away from narrative fiction filmmaking in the 1970s and 1980s to focus on documentary, and it is in that genre that we can most easily chart the continuing use of ethnofiction-style 
techniques. For example, the work of Hara Kazuo, particularly Extreme Private Eros: Love Song 1974 (Gokushiteki erosu: renka 1974, 1974) and The Emperor's Naked Army Marches On (Yuki yukite shingun, 1987) continued the provocative use of the camera modeled by Rouch and Imamura. Markus Nornes has argued for the early to mid-1970s as a break in documentary filmmaking, "with new filmmakers rejecting the dominant conception of documentary practice" and turning to more individualist models rather than collective filmmaking practice (2002, p. 64). At the same time, fiction filmmaking practices were also changing as the studio system contracted due to a decline in audience attendance, which plummeted sharply from a peak in 1958. Critics, scholars, and filmmakers themselves note the decline of the documentary genre in the 1980s, characterizing the period as one of "groping in the darkness", to quote the title of the 1998 Yamagata International Documentary Film Festival (Nornes 2002). As the students of Hara and Suzuki Shiroyasu, another prominent documentary filmmaker of the 1970s, began to produce their own documentary films, Nornes argues that a focus on the individual self continued into the 1990s in such films as Kawase Naomi's Embracing (Nusumarete, 1992) and he "self-nudes" of Kamioka Fumie, Wada Junko, and Utagawa Keiko (Nornes 2002, pp. 64-65). A number of these early 1990s films are "fake documentaries" (Nornes 2002, p. 65), involving an element of fictionalization reminiscent of ethnofiction. Rather than focusing on ethnofiction in Japanese documentary cinema however, I am interested in how ethnofiction techniques became the commonsense approach to representing everyday life in commercial narrative film, and the divergence between this trend and current discourses on ethnofiction in visual anthropology today. The next sections will return to the commercial fiction film and the field of visual anthropology to consider how ethnofiction is practiced and discussed in the 2000s. As a secondary point, the discussion of Hou Hsiao Hsien's Café Lumière below demonstrates the flow of ethnofiction-style techniques not only across the boundary of fiction and documentary genre films, but also geographically, as the Taiwanese director adapted ethnofiction approaches to plan and film a story set in Japan.

\subsection{Contemporary Ethnofictions: Café Lumière}

Imamura eventually returned to fiction filmmaking, while the ethnofiction-style approach demonstrated in A Man Vanishes remains apparent in contemporary films made in Japan today. For example, Hou Hsiao Hsien's Café Lumière draws from a number of the ethnofiction techniques discussed above, including ethnographic research as the basis for narrative development, and the use of hidden or surreptitious cameras to film events as they unfold in public spaces. Café Lumière was commissioned by Shōchiku studios to commemorate the centenary of Ozu's birth. Hou's film was originally planned as one of three short films to celebrate Ozu's centenary, though the others were never made and Hou's expanded to feature length. The quiet naturalistic narrative follows protagonist Yōko, played by singer Hitoto Yō, as she travels by train through the centre of Tokyo, visiting a bookshop run by her anthropologist friend Hajime to research a book about a Taiwanese composer. Later, we learn that Yōko is pregnant by a Taiwanese partner now living in Thailand, and considering her options for the future.

Hou based Hitoto's character on a Taiwanese friend living in Tokyo and working as a freelance writer. In interviews, Hou has emphasized basing his film characters on real people, and mimicking the mechanics of their everyday lives. The narrative development proceeded alongside character development, based on real events and experiences told to the director.

... the main outline of the story came out of conversations with friends and what I knew of their backgrounds. It usually works like this. I'd start with a concept, and develop a structure, and then I'd start exploring some concrete instances (Hou and Liu 2008, p. 181).

Research included scoping the landscape of Tokyo, "trying to figure out which part of Tokyo, and on which railway line, people like my characters usually lived" (Hou and Liu 2008, p. 181). As Yōko tries to imagine a future life with the Taiwanese father of her child, the shifting distinctions between Japan and Taiwan are mirrored in the star persona of Hitoto, born to a Taiwanese father and Japanese 
mother, and in her character's research on Taiwanese composer Jiang Wen-Ye (1910-1983), who left his Japanese wife to teach in occupied China (1938). Jiang's real life mirrors Yōko's fictional situation in that the Taiwanese father of her child has moved to Thailand and she must decide whether to join him. In this way, Hou creates characters and narratives by weaving together information based on ethnographic research conducted among Taiwanese friends living in Japan, the family background of his leading actress, and the historical figure of a Taiwanese composer.

I have a friend called Kosaka who married a Taiwanese. Part of the storyline was copied from her life. She was a 'cafe girl.' What I mean is that she did all her work at the coffee shop, including having meetings with people, writing, and organizing her work. The funniest was the day when she took an entire suitcase to the coffee shop when she met with us. She put some of her stuff into her suitcase and took some more out while she was explaining herself to us. Before we came, she was waiting for her parents at the coffee shop to pick up her kid. The coffee shop was her office. This part of the story came from her (Hou and Liu 2008, p. 181).

The settings, including Yōko's family home, were similarly borrowed from friends and a whole sub-plot concerning visiting family graves was inspired by the director learning about the August O-Bon festival and its customs by observing friends' activities in this month (Hou and Liu 2008, p. 181). The film layers these elements over a naturalistic representation of Tokyo, privileging the environmental sounds of the city and the surrounding countryside over dialogue and emphasizing the capture of the everyday sounds of real life. Anthropologist Hajime is even shown recording the sounds of the Tokyo railway system for an ethnographic art project, in a self-referential scene that mirrors the process of the ethnographer-director.

In part due to the constrictions of filming these scenes, the style of Hou's film suggests similarities with the quasi-documentaries and ethnofiction films of the late 1960s and 1970s. Hou was unable to secure permission from Japan Railways to film on the Yamanote line (Hou and Liu 2008, p. 181). As a result, the camera crew were forced to go undercover, packing minimal equipment into backpacks and assembling camera rigs on the train (Hou and Liu 2008, p. 182). Cameramen were asked, "to keep a low profile and do it casually" (Hou and Liu 2008, p. 182), operating according to similar principles to the ethnofiction filmmaker. Like Rouch and Imamura before them however, the camera sometimes gave the filmmakers away. "We said 'shoot it secretly' but all of our staff laughed about it because we were pretty obvious" (Hou and Liu 2008, p. 182). Hou did exercise directorial agency over particular shots; for example, the scene in which Yōko and Hajime pass one another in separate trains had to be shot eighteen times. Nonetheless, the filming style and dialogue emphasize a sense of reality, as Hajime muses that his recordings of train sounds might assist a criminal investigation, "Someone might need to hear a tape as evidence of something".

Café Lumière demonstrates the on-going use of ethnofiction-style filmmaking techniques and narrative development in feature films made in Japan today. At the same time, the increasing availability of filmmaking equipment for non-professional filmmakers, including researchers, has encouraged an increase in the use of filmmaking for research purposes. While filmmaking has had a central place in visual ethnography since the 1950s, the cheaper equipment and editing software currently available has increased the number of graduate students and ethnographic researchers using filmmaking for research purposes in Japan. As a scholar of classical narrative Japanese cinema turned documentary filmmaker, I was interested in how these researchers understood the history of ethnographic filmmaking in Japan, including the development of ethnofiction. In the concluding paragraphs, I present some observations on contemporary understandings of the development of ethnofiction techniques in Japanese visual anthropology. 


\section{Discussion: Ethnofiction as Research Practice at The National Museum of Ethnography}

With my background in Japanese film studies, the texts discussed above were at the forefront of my mind as I set out to make my own documentary film about the memories of early postwar audiences in the cinema theatres of the Kansai region. I joined a filmmaking study group at The National Museum of Ethnography, home to leading practitioner-researchers making anthropologically-influenced ethnographic films, including Professor Omori Yasuhiro, one of Jean Rouch's last students. Rouch's approach has been the subject of much discussion at the museum, known colloquially as Minpaku. In part, this is due to Professor Omori's connections, but conversations with and around Rouch and his methods are also sustained by Minpaku's relationship with the University of Manchester in the United Kingdom, the Granada Center at the university, and the Filmmaking for Fieldwork collective working there. Kawase Itsushi, Associate Professor at Minpaku, facilitates connections between the Osaka-based institute and counterparts in Manchester, and many researchers and graduate students from Minpaku enroll on the summer filmmaking courses offered by the Granada Center for Visual Anthropology, and the associated Filmmaking for Fieldwork collective. Manchester visual anthropology situates the work of Jean Rouch as an example of the origins of ethnofiction in documentary cinema. Rouch's cinema verité, using the camera to instigate events rather than documenting events that spontaneously occurred in the vicinity of the camera, is a common approach to ethnofiction at Minpaku.

In 2016, I was included in a small research group dedicated to studying ethnofiction filmmaking, and screened Imamura's A Man Vanishes and A History of Postwar Japan as Told by a Bar Hostess at consecutive meetings. The attending graduate students and researchers had not viewed Imamura's films before, and their response to the screenings was immediate interest in this home-grown example of ethnofiction filmmaking developing around the time of its French counterpart. One graduate student later wrote that he was "stunned by how innovative his films were/are". The student particularly praised "the reflexive viewing method Imamura utilized in A History of Postwar Japan, where Madam Onboro talks out her opinions and memories while viewing the footage of war", noting that this "is one of the trends in contemporary anthropological filmmaking". The question "What is truth?" raised by Hayakawa Yoshie in A Man Vanishes was also identified as particularly relevant to the group members' own fieldwork and filming.

Minpaku anthropologists were open to the inclusion of Imamura in the historiography of the development of ethnofiction filmmaking techniques, and like Kamei Fumio before us, we agreed on the possibility of ethnofiction as a simultaneous development, occurring in France and Japan at around the same time. I offer this short auto-ethnographic vignette in closing not to justify the argument above with the agreement of a small group of visual anthropologists, but to suggest that researchers and filmmakers in various fields may be more open to the blurring of boundaries between visual anthropology and film studies, and between narrative fiction film and feature film, than the current organization of disciplines and genres suggests. The Minpaku discussions suggested to me the importance of overcoming the organizational barriers that have been constructed around geographical and genre definitions to understand ethnofiction as a truly global innovation, with certain regional specificities. Scholars of studio-era narrative cinema collaborating with visual ethnographers and practice-based filmmaker researchers can blur the constructed boundaries between the fields, revealing alternative historiographies of innovation and development that give a more holistic picture of the productive intersections of fiction and non-fiction film.

What might this ultimately mean? The humanities and social sciences, within which film studies and anthropology are generally housed, are positioned as fields of enquiry into the human condition, broadly defined. Likewise, documentary cinema purports to reveal the conditions and environment in which we exist. Tracing ethnofiction and associated techniques through early actuality film, news production, war propaganda, classical narrative fiction film, and documentary cinema both for research and entertainment purposes emphasizes the limitations of the camera in telling the whole story, and reveals our reliance on discourse about the filmmaking process to better understand what we are watching. The persuasive influence of discourse suggests the importance of getting our stories 
straight, and that includes the story of how ethnofiction developed in Japanese and East Asian cinema. Understanding ethnofiction as a global innovation with regional specificities gives us a clearer picture of its emergence, development, uses, and abuses, revealing the blurry line between truth and fiction to be geographically and temporally shared.

Funding: This research received no external funding.

Acknowledgments: I am grateful for the kind support of researchers at The National Museum of Ethnography in Osaka, Japan, including Kawase Itsushi, Yanohara Yushi, and Muratsu Ran. Jamie Coates gave much appreciated feedback on early drafts of this paper, and Michael Raine and Marcos Centeno's guidance on the abstract greatly shaped the final version. I also appreciate the feedback and suggestions of my two autonomous reviewers.

Conflicts of Interest: The author declares no conflict of interest.

\section{Filmography}

A History of Postwar Film as Told by a Bar Hostess/Nippon sengoshi: Madamu Onboro no seiketsu, dir. Imamura Shōhei, Imamura Productions, 1970.

A Man Vanishes/Ningen Jōhatsu, dir. Imamura Shōhei, Imamura Productions, 1967.

A.K.A Serial Killer/Ryākusho: renzoku shasatsuma, dir. Adachi Masao et al., 1969 (screened 1975)

Café Lumière/Kōhi jikō, dir. Hou Hsiao-Hsien, Shōchiku, 2003.

Carmen Comes Home/Karumen kokyo ni kaeru, dir. Kinoshita Keisuke, Shōchiku, 1951.

Chronicle of a Summer/Chronique d'un été, dir. Jean Rouch, Argos Films, 1961.

Dawn of Freedom/Ano hata o ute, dir. Abe Yutaka and Geraldo de Leon, Toho, 1942.

Fighting Soldier/Tatakau heitai, dir. Kamei Fumio, Toho, 1939.

Geisha Riding in Rickshaws/Geishas en jinrikisha, dir. Francois-Constant Girel, Lumière catalogue, 1898.

In Search of the Unreturned Soldiers in Malaysia/Mikikanhei o otte-Marei-hen, dir. Imamura Shōhei, Tokyo Channel 12, 1971.

In Search of the Unreturned Soldiers in Thailand/Mikikanhei o otte-Tai-hen, dir. Imamura Shōhei, Tokyo Channel 12, 1971.

Japanese Actors/Auteurs japonais, dir. Francois-Constant Girel, Lumière catalogue, 1898.

Japanese Fencing/Escrime au sabre japonaise, dir. Francois-Constant Girel, Lumière catalogue, 1897.

Kamigami no Fukaki Yokubō/The Profound Desire of the Gods, dir. Imamura Shōhei, Imamura Productions, 1968.

Outlaw Matsu Returns/Muhomatsu kokyo ni kaeru, dir. Imamura Shōhei, Tokyo Channel 12, 1973.

The Ainu in Yeso/Les Aïnous à Yéso, dir. Francois-Constant Girel, Lumière catalogue, 1897.

The Insect Woman/Nippon konchūki, dir. Imamura Shōhei, Nikkatsu, 1963.

The Rickshaw Man/Muhomatsu no issho, dir. Inagaki Hiroshi, Toho, 1958.

\section{References}

Anonymous. 1910. Katsudo Shashinkai [Moving Picture World], July 21.

Higson, Andrew. 1995. Waving the Flag: Constructing a National Cinema in Britain. Oxford: Clarendon.

Hori, Hikari. 2018. Promiscuous Media: Film and Visual Culture in Imperial Japan, 1926-1945. Ithaca and London: Cornell University Press.

Hou, Hsiao-Hsien, and Petrus Liu. 2008. Cinema and History: Critical Reflections. Inter-Asia Cultural Studies 9: 173-83.

Imamura, Shōhei. 1997. My Approach to Filmmaking. In Shohei Imamura. Edited by James Quant. Toronto: Toronto International Film Festival Group, pp. 125-28.

Imamura, Shōhei. 2001. Toru: Kannu kara Yamiichi e. Tokyo: Kōsakusha.

Imamura, Shōhei. 2017. "Betwixt fiction and documentary" [Fikushon to Dokyumentari no Awai de]. Translated by Bill Mihalopoulos. Asian Cinema 28: 101-5.

Kasza, Gregory. 1993. The State and the Mass Media in Japan 1918-1945. Berkeley: University of California Press.

Komatsu, Hiroshi. 1994. Transformations in Film as Reality (Part One): Questions Regarding the Genesis of Nonfiction Film. Trans. Aaron Gerow. Documentary Box 5: 1-5. Available online: https:/ /www.yidff.jp/ docbox/5/box5-1-e.html (accessed on 19 December 2018). 
Laprévotte, Gilles. 1997. Shōhei Imamura: Human, All Too Human. In Shohei Imamura. Edited by James Quant. Toronto: Toronto International Film Festival Group, pp. 101-7.

Mihalopoulos, Bill. 2008. Becoming Insects: Imamura Shōhei and the Entomology of Modernity. In The Power of Memory in Modern Japan. Edited by Sven Saaler and Wolfgang Schwentker. Folkestone: Global Oriental, pp. 277-90.

Naimushō keihōkyoku 1941. Eiga kensetsu nenpō.

Nakata, Toichi. 1997. Shohei Imamura Interview. In Shohei Imamura. Edited by James Quant. Toronto: Toronto International Film Festival Group, pp. 107-24.

Nornes, Abé Markus. 2002. The Postwar Documentary Trace: Groping in the Dark. Positions 10: 39-78. [CrossRef]

Nornes, Abé Markus. 2003. Japanese Documentary Film: The Meiji Era through Hiroshima. Minneapolis: University of Minnesota Press.

Richie, Donald. 2005. A Hundred Years of Japanese Film: A Concise History, with a Selective Guide to DVDs and Videos. Tokyo and New York: Kodansha International.

Sjöberg, Johannes. 2008. Ethnofiction: Drama as a creative research practice in ethnographic film. Journal of Media Practice 9: 229-42. [CrossRef]

Stoller, Paul. 1992. The Cinematic Griot: The Ethnography of Jean Rouch. Chicago: Chicago University Press.

Sugiyama, Heiichi. 1990. Imamura Taihei. Tokyo: Libroport.

Toki, Akihiro, and Kaoru Mizoguchi. 1993. A History of Early Cinema in Kyoto, Japan (1896-1912). Cinemagazinet! No. 1. Available online: http:/ / www.cmn.hs.h.kyoto-u.ac.jp/NO1/SUBJECT1/INAEN.HTM (accessed on 31 January 2017).

(C) 2019 by the author. Licensee MDPI, Basel, Switzerland. This article is an open access article distributed under the terms and conditions of the Creative Commons Attribution (CC BY) license (http:// creativecommons.org/licenses/by/4.0/). 